\title{
Impact of Government Policy on Tuna Commodities in Malang District, East Java
}

\author{
Yeni Sari Wulandari ${ }^{*}$, Suhartini ${ }^{2}$, Hery Toiba ${ }^{2}$ \\ ${ }^{1}$ Department of Agribusiness, Faculty of Agriculture, Singaperbangsa Karawang University, (41361) \\ ${ }^{2}$ Department of Socio-Economics, Faculty of Agriculture, Brawijaya University, Veteran St., (65145)
}

Received: 7 January 2019; Revised: 19 November 2020; Accepted: 1 December 2020

\begin{abstract}
Tuna commodity turns out to be one of fishery commodities contributing to an export increase by value above the average of $18.57 \%$. This is an opportunity for Indonesia to improve the country's economy by utilizing existing fishery resources. Thus, government policies are needed in order to support the export performance of fishery products. This research was conducted to determine the impact of government policies toward tuna fish commodities in Malang. The method used was the Policy Analysis Matrix (PAM) that aimed at knowing the impact of government policies on tuna commodities. In this study, the respondents were 30 tuna fishermen at TPI Pondokdadap. The results of analysis showed that there were subsidies, taxes, and trade restrictions in input factor. Nonetheless, in output factor, fishermen did not receive subsidies. The existence of a policy on input is very helpful for fishermen so as to reduce production costs, while in the output policy the community receives more benefits at low output prices. However, it can be seen from the DRC and PCR values that they are less than one. This means that the tuna fish commodity in Malang still has comparative and competitive advantages in competitiveness.
\end{abstract}

Keywords: policy; impact; PAM; tuna; fish

\section{How to Cite:}

Wulandari, Y. S., Suhartini, \& Toiba, H. (2020). Impact of Government Policy on Tuna Commodities in Malang District , East Java. HABITAT, 31(3), 169-176. https://doi.org/10.21776/ub.habitat.2020.031.3.20

\section{Introduction}

In 1994, Indonesia has been a part of WTO (World Trade Organization) by a published Law number 7 year 1994 concerning about Agreement Establishing the World Trade Organization. This implies that Indonesia has been in line with free trade, thus, each country must increase its competitiveness by whole products covering fishery commodity. Free trade brings positive impacts as well as negative impacts on Indonesia. The positive impacts are seeing on the point of quality and quantity of products that link to the opportunity of export to gain the foreign exchange. In turn, the negative impact is about the more imported commodity exists, the more it becomes downtrodden. Therefore, the fishery commodity in Indonesia is demanded to compete to other countries (Putra, 2016).

In industrialization era, fishery sector turns to have a potential term to develop the economy

${ }^{*}$ Corresponding Author.

E-mail: yenisariwulandari@gmail.com Telp: +62-82233551553 of Indonesia regarding to be a fishery commodity exporting country. Nowadays, Indonesia ranks 9th as the largest exporting country in fishery commodity. However, Indonesia got defeated by its competitors such as Thailand and China. This happens because the highest exporting countries have good comparative and competitive advantages both in management and technology (Poernomo and Heruwati, 2011).

Based on BPS data, in period of 20162017, several fishery commodities experienced an export value of fishery product about $8.12 \%$ of USD 3.78 billion in 2016 to USD 4.09 billion in 2017. One of commodities that contributes to an export increasing is Tuna Tongkol Cakalang (TTC) that advanced above average from export value of $18.57 \%$. This is such an opportunity of Indonesia to repair a country's economy to the advantage of fishery resources. As the highest exporting fishery commodity, it is geographically worthy in such located between Indian Ocean that makes Indonesia rich of marine resources. Hence, Tuna commodity should be managed as well in order to face both national and 
international competition (Kementerian Kelautan dan Perikanan, 2018).

In the marine and fishery sector, government assistance should be involved in growing the production and the sustainability of fishery management. The assistance can be categorized as fishery subsidy. One of examples of government facilitation is strengthening and developing of foreign marketing in order to support the export performance of fishery products. Furthermore, government also provides several types of fishery subsidies.

There have been much literatures that explain about government's policies toward the sustainability of fishery resources. (Ghofar, 2008) They are procurement and modernization of vessels and fishing gear; provision of operational costs; providing access to capital; infrastructure procurement; marketing and promotional assistance; introduction of skills in fishing techniques; and other social assistances. Apart from that according to (Hermawan, 2006) fuel is a very crucial production input for fisheries business covering $70 \%$ of operational costs for fishing activities. Government policy's support is needed in developing the fisheries sector in order to increase competitiveness and fish exports, likewise to increase foreign exchange. The research's finding (Muchlisin et al., 2012) explained that the fuel component was the largest component in Aceh Besar fishermen's fishing activities, which was around $40 \%-73 \%$ (on average $57.9 \%$ ) of the total operating costs. If the fuel subsidy is removed, the average fishermen's income will decrease by $89.5 \%$. (Rilus, 2012) explained that the impact of this policy can be seen from changes in the amount of effort and condition of fish stocks at the utilization of maximum economic yield. This happened because subsidies are an economic instrument in the management of fishery resources. It is suspected that with the provision of subsidies, the amount of effort will increase so that the rate of utilization of these fishery resources will be faster. From some existing literatures, it can be concluded that the existence of government policy's support is very helpful for the community, particularly for the capture fisheries sector, however, these literatures only explain the impact of policies in general on fishery resources. Thus, it is necessary to do further research on the impact of government policies on the competitiveness of fishery commodities.
This research attempted to see the existence of government policies that effected on Tuna commodity. The purpose of study aimed at recognizing the impacts of government policies toward Tuna commodity competitiveness through PAM analysis.

\section{Research Methods}

The data gained from survey on lifeboat fishermen in TPI (Fish auction place) Pondokdadap, Sumbermanjing District, Malang Regency that was held on August until September 2018. The researcher considered the location due to it was the biggest production of Tuna in East Java. The information covered the type of boat, fishermen characteristic, and fishermen's income. The respondents were defined by using simple random sampling that got 30 respondents.

The quantitative method, Policy Analysis Matrix (PAM), was employed to analyse data about Tuna competitiveness and government's impacts. This is similar to the previous research that employed PAM analysis (Elbadawi, 2012).

PAM turns out as a popular method to analyse the competitiveness and policies' impact on a certain commodity. PAM aimed at analysing both comparative and competitive advantages by calculating benefit levels of private and social as well as transfer effect from a policy (Pearson, 2005)

Based on Monke and Pearson in Mahatama and Miftah (2013), this research consists of two stages, the competitiveness analysis using Policy Analysis Matrix (PAM), and competitiveness analysis with policy using sensitivity analysis. The data analysis has several stages. First, defining input of costs used in conducting Tuna business, either fixed cost or variable cost. Second, identifying tradable or non-tradable input components. PAM matrix and impact policies indicators can be seen in Table 1 as follow.

Table 1. Policy Analysis Matrix

\begin{tabular}{lcccc}
\hline & & \multicolumn{3}{c}{ Cost } \\
\cline { 3 - 4 } Variable & Revenue & $\begin{array}{c}\text { Tradable } \\
\text { inputs }\end{array}$ & $\begin{array}{c}\text { Non } \\
\text { Tradable } \\
\text { inputs }\end{array}$ & \\
\hline Actual Price & $\mathrm{A}$ & $\mathrm{B}$ & $\mathrm{C}$ & $\mathrm{D}$ \\
Social Price & $\mathrm{E}$ & $\mathrm{F}$ & $\mathrm{G}$ & $\mathrm{H}$ \\
$\begin{array}{l}\text { Divergence } \\
\text { effect }\end{array}$ & $\mathrm{I}$ & $\mathrm{J}$ & $\mathrm{K}$ & $\mathrm{L}$ \\
\hline
\end{tabular}

Source : (Monke and Pearson, 1989) 
Description :

A : Individual Revenue

B : Tradeable Input

C : Domestic factor input

D : Private Profits / Individual Income

E : Social Revenue

F : Tradeable Input

G : Domestic factor input

H : Social Profit / Social Income

I : Output Transfer

A : Input Transfer / Tradeable Input Transfer

$\mathrm{K}$ : Domestic Transfer Factor

L : Net Transfer / Net Transfer Policy

According to Pearson (2005) differences in private profits before and after policy indicating the effect of policy changes on competitiveness at the actual price level (market prices). The approach that is often used as an indicator for measuring the competitiveness of a commodity are comparative advantage and competitive advantage. From the above PAM matrix arrangement, the following formula can be found as follow:

\subsection{Economic Efficiency Analysis}

a. Comparative advantage:

\section{DRCR = G / (E - F $)$}

DRCR showed the ability of economic activity to fund domestic factors at social prices. If DRCR > 1, it means that Tuna business did not have comparative advantage or it can be said it was not efficient economically in the use of domestic resources, on the contrary, if the DRCR $<1$, it means that the tuna fish business has a comparative advantage, or in oher word, the effort was carried out efficiently in dividing domestic resources.

b. Competitive advantage:

\section{PRCR = C / (A - B)}

Competitive advantage is the ability of a region to gain economic advantages over profits that are able to be achieved by competitors in the market as well as in the same industry. If PRCR $<1$, it means the Tuna business did not have competitive advantage, if PRCR > 1, it means the Tuna business did not have competitive advantage, and if PRCR $=1$, it means the Tuna business in a balance condition, or it did not have any advantages but it is even.

\subsection{Government Policy Analysis}

a. Input policy

Input transfer :

$$
(\mathbf{J})=(\mathbf{B})-(\mathbf{F})
$$

Available online at HABITAT website: http://www.habitat.ub.ac.id

ISSN: 0853-5167 (p); 2338-2007 (e)
The value of $\mathrm{J}$ showed the amount of transfer from producer to government through the application of import policy.

Nominal Protection Coefficient Input :

NPCI $=\mathbf{B} / \mathbf{F}$

NPCI <1, indicated that the government reduced the price of tradable inputs in domestic market below world prices, thus, fishermen as consumers with those inputs were benefited from the low prices of production facilities.

Factor Domestic Transfer :

$$
(\mathbf{K})=(\mathbf{C})-(\mathbf{G})
$$

If the value of $\mathrm{K}>0$, it means that the policy protected fishermen by providing subsidies. If $\mathrm{K}<0$, it means that the policy did not protect fishermen.

\section{b. Output Policy \\ Transfer Output : $(I)=(A)-(E)$}

If the value of $\mathrm{I}>0$, it indicated the amount of transfer from the community to the producers (people buy with higher price than the actual amount). If the value of $\mathrm{I}<0$, it indicates the amount of transfer from producers to society (people buy with lower price than the actual amount).

\section{$\mathrm{NPCO}=\mathrm{A} / \mathrm{E}$}

$\mathrm{NPCO}<1$, it demonstrated that government policy causes private prices lower than social prices. NPCO $>1$, it demonstrated that government policy causes private prices higher than social prices.

c. Input-Output Policy

$$
\mathbf{E P C}=(\mathbf{A}-\mathbf{B}) /(\mathbf{E}-\mathbf{F})
$$

If the EPC value is $<1$, it represents that the government's incentive policy for Tuna business is ineffective. EPC > 1, it represents that the government's incentive policy for Tuna business is effective.

$$
\mathbf{P C}=\mathbf{D} / \mathbf{H}
$$

If $\mathrm{PC}>1$, it showed that government intervention made fishermen get a higher profit than consumers, otherwise, if $\mathrm{PC}<1$, it showed that government intervention made fishermen get a lower profit than consumers.

\section{$\mathbf{S R P}=\mathbf{L} / \mathbf{E}$}

If the SRP value > 0 (positive), it means that producers spent less on production costs, so that it increased gross profit. On the contrary, if the SRP value $<0$ (negative), it means that producers spent more on production costs, thereby it reduced gross profits, and if $\mathrm{SRP}=0$, it means that government policies did not have an impact on Tuna business costs. 


\section{Results and Discussion}

\subsection{Input-Output Analysis}

In analysing using the PAM method, it is necessary to compile the input and output data of the tuna business. This matrix is assembled based on revenue data and production costs which are divided into two parts, those are private and economic prices (social opportunity cost). Those two types of prices have been influenced by government policy. Meanwhile, social prices occur in perfect competitive markets or it is close to world prices. Moreover, they are only distinguished by transportation costs to the location of the farm. The aimed was to know the competitiveness and impact of policies on tuna commodities. The data employed in this study are tuna production data from TPI Pondokdadap in 2018.

The first step of this analysis was determining tradable and non-tradable inputs for each input of tuna business input. After that, it was determining shadow prices of the exchange rate. Based on Bank Indonesia in 2018, the official exchange rate was IDR 14.735 , thus, it can be calculated the shadow exchange rate itself. To calculate the shadow prices for the exchange rate, a standard conversion factor is calculated by using the formula as follow:

$$
\begin{gathered}
S C F t=\frac{M t+X t}{(M t+T M t)+(X t-T X t)} \\
=\frac{2.304+2.223}{(2.304+37,5)+(2.223-3)} \\
S C F t=0,99
\end{gathered}
$$

If the import value was IDR 2.304.63 trillion; the export value was IDR 2.223.37 trillion; the import tax value was IDR 37.500 billion and the export tax was IDR 3.000 billion. Therefore, the standard conversion factor was
0.99. Furthermore, after knowing the SCF, it was calculated with the shadow price of the money exchange rate (SER), with the formula as follow:

$$
\begin{gathered}
S E R=\frac{O E R}{S C F} \\
=\frac{R p 14.735,84}{0,99} \\
S E R=R p 14.884,69
\end{gathered}
$$

Hence, it was obtained the SER or the shadow exchange rate of IDR. 14.884.69. Then, it was determining the output price and tradable input. To define the shadow output price (social) was using the average export price converted in the Shadow Exchange Rate (SER). The export price is free prices on board (f.o.b) that is the price at the port, while, the determination of the shadow input price in this study employs a conversion factor, as used by previous researchers (Gray, 1992).

Table 2 reveals that most of the production factors for tuna such as boats, fishing rods, hooks, diesel, oil, LPG, and gasoline have higher social prices than private prices or the actual prices in the market. This happened due to the fuel including oil, diesel and gasoline, received subsidies from the government about IDR.935/liter for oil; IDR 5.077/liter for diesel; IDR 495/liter for gasoline. Meanwhile, other inputs such as fishing rods, floats, nets, and LPG, the actual prices are higher than the social prices. This happens because there are tax and transportation cost to get the things. Besides, the social price of tuna output is IDR 75.863 and the actual price is IDR $37.000 / \mathrm{kg}$ with the average output of tuna about $378.744 \mathrm{~kg}$. Hence, the economic income is bigger than in financial terms because the social price of tuna output is higher than the actual price with a difference price of IDR 38,863 per kg.

Table 2. The Value of Private Prices and Social Prices of Input - Output in Tuna Fish Business

\begin{tabular}{lccc}
\hline \multicolumn{1}{c}{ Variable } & Unit & $\begin{array}{c}\text { Private Price } \\
(\text { Rp/Unit) }\end{array}$ & $\begin{array}{c}\text { Social Price } \\
\text { (Rp/Unit) }\end{array}$ \\
\hline Fishing Boat & Unit & 500.000 .000 & 561.321 .320 \\
Fishing rod & Unit & 215.385 & 250.000 \\
Float Net & Unit & 50.000 & 45.733 \\
Net & Unit & 50.000 & 39.065 \\
Hook & Unit & 81.000 & 103.906 \\
Solar & Liter & 5.150 & 10.227 \\
Machines Oil & Liter & 33.000 & 33.935 \\
LPG & Tube & 22.000 & 26.323 \\
Gasoline Generator & Liter & 10.000 & 10.495 \\
Tuna & Kg & 37.000 & 75.863 \\
\hline
\end{tabular}


In table 3 , the analysis of both financial and economic of tuna business displays that the domestic input costs are higher than the tradable input costs. The high domestic cost is due to the fact that the price of domestic goods reflects the actual price, while the price of tradable goods is lower than the price of domestic goods because there are several input goods that are subsidized by the government covering diesel fuel, thus, they do not reflect the actual price. However, even though domestic costs are higher, the largest expenditure cost is diesel fuel which is included in the tradable input category. The average cost of diesel fuel is IDR 74.160.000.
In the venue of research, the shadow prices for tradable inputs are higher than the actual prices. The shadow price for each input is IDR 37.421.421; -IDR 430.770, -; IDR. 930.670, -; IDR 182.935, -; IDR 156.262, -; IDR 41.543, -; IDR 10.427, -; IDR. 169.677, -; and IDR 26.324, - while the actual price of each input paid by tuna entrepreneurs is IDR 22.222.222; IDR. 333.333, ; IDR 200.000; IDR. 133.333, -; IDR. 133.333, -; IDR 5.150, -; IDR 165.000; and IDR. 22.000, By the existence of the subsidy, tuna entrepreneurs paid less than the usual prices.

Table 3. Financial and Economic Analysis of the Tuna Fish Business

\begin{tabular}{|c|c|c|c|c|c|}
\hline \multirow[t]{2}{*}{ No } & \multirow[t]{2}{*}{ Variable } & \multicolumn{2}{|c|}{ Financial Analysis } & \multicolumn{2}{|c|}{ Economic Analysis } \\
\hline & & Tradeable & Non Tradeable & Tradeable & Non Tradeable \\
\hline \multirow[t]{7}{*}{1} & Depreciation of Equipment & & & & \\
\hline & 5 GT Fishing Boat & $22,222,222$ & & $37,421,421$ & \\
\hline & Fishing rod & 333,333 & & 430,870 & \\
\hline & Fishing reels & 200,000 & & $930,669.58$ & \\
\hline & Float Net & 133,333 & & 182,935 & \\
\hline & Net & 133,333 & & 156,262 & \\
\hline & Hook & 21,600 & & 41,563 & \\
\hline \multirow[t]{10}{*}{2} & Infrastructure & & & & \\
\hline & LPG & $3,168,000$ & & $3,790,634$ & \\
\hline & Solar & $74,160,000$ & & $150,154,083$ & \\
\hline & Machines Oil & $11,880,000$ & & $12,216,757$ & \\
\hline & Jenset Oil & 960,000 & & 814,450 & \\
\hline & Gasoline Generator & $14,400,000$ & & $15,113,568$ & \\
\hline & Ice & & $52,800,000$ & & $52,800,000$ \\
\hline & Water & & $1,800,000$ & & $1,800,000$ \\
\hline & Drinking water & & $3,648,000$ & & $3,648,000$ \\
\hline & Groceries & & $38,832,000$ & & $38,832,000$ \\
\hline 3 & Labor & & $129,587,214$ & & $129,587,214$ \\
\hline 4 & Transportation costs & & $6,400,000$ & & $6,400,000$ \\
\hline 5 & Handling costs & & $8,000,000$ & & $8,000,000$ \\
\hline \multicolumn{2}{|c|}{ Total Costs } & \multicolumn{2}{|c|}{$368,679,037$} & \multicolumn{2}{|c|}{$462,320,427$} \\
\hline \multicolumn{2}{|c|}{ Revenue } & \multicolumn{2}{|c|}{$649,232,640$} & \multicolumn{2}{|c|}{$1,324,576,448$} \\
\hline \multicolumn{2}{|c|}{ Income } & \multicolumn{2}{|c|}{$280,553,603$} & \multicolumn{2}{|c|}{$862,256,021$} \\
\hline
\end{tabular}

Tuna business revenue in the research area was obtained by multiplying the amount of tuna output produced by the price per $\mathrm{kg}$. The average of the actual output price of tuna was IDR 37.184, while the average output of tuna produced was $378.744 \mathrm{~kg}$ per year. Financially, the income received in the tuna business in one year was IDR 649.232.640 per boat.

Economically, the production input that cost highest was diesel fuel that reaches $36 \%$ of the total cost. The next highest input cost was for ice purchasing about $26 \%$ and groceries about $19 \%$ of the total cost. This is in line to (Mira, 2014) where the reduction in subsidies due to the increase in fuel prices has an impact on the capture fisheries sector. This causes a decrease in output, input, labor, exports and household demand. So that some households shift their demand to aquaculture, because at the same time the price of cultivated fish has fallen. The effect of the increase in fuel prices on the capture fisheries sector is higher than that the aquaculture 
sector. It was because of the cost of fuel dominated the total cost of capture fishery business about $45 \%$.

\subsection{PAM Analysis}

In the PAM analysis method, after identifying the tuna fisheries business both financially and economically, then an analysis of the impact of government policies on tuna commodities at TPI Pondokdadap, Sumbermanjing District, Malang Regency was carried out. The results of the PAM analysis on tuna business at TPI Pondokdadap were presented in the Table 4:

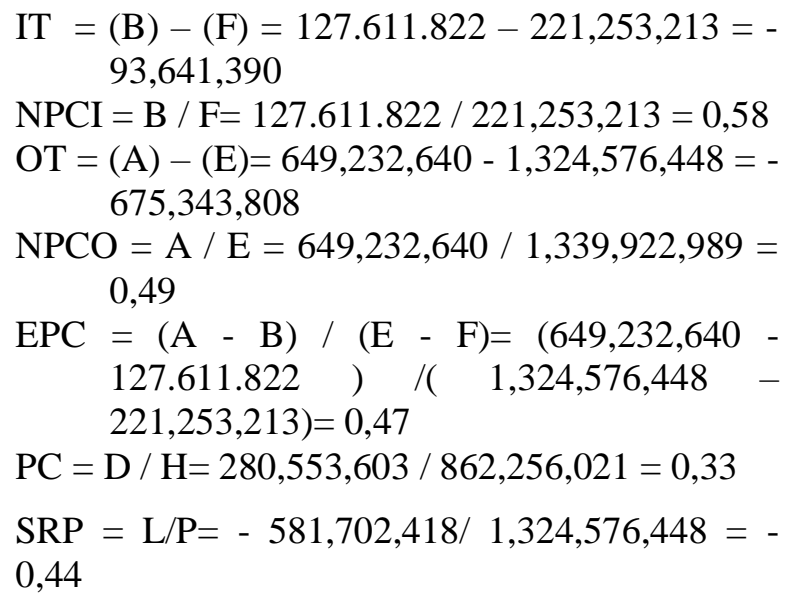

Table 4. Analysis of the Policy Analysis Matrix (PAM) in Tuna Fish Business

\begin{tabular}{lcccc}
\hline \multirow{2}{*}{ Variable } & \multirow{2}{*}{ Revenue } & \multicolumn{3}{c}{ Costs } \\
\cline { 3 - 5 } & & Tradeable & $\begin{array}{c}\text { Non tradeable } \\
\text { Inputs }\end{array}$ & Profit \\
\hline Private Price & $649,232,640$ & $127,611,822$ & $241,067,214$ & $280,553,603$ \\
Social Price & $1,324,576,448$ & $221,253,213$ & $241,067,214$ & $862,256,021$ \\
Divergence Effect & $(675,343,808)$ & $(93,641,390)$ & - & $(581,702,418)$ \\
\hline
\end{tabular}

Based on the table above, it can be concluded that the social acceptance is higher than the private price. This is due to the differences in the output price of tuna. The private price of tuna was IDR 37.184 per $\mathrm{kg}$, while the social price of tuna was IDR 75.863 per $\mathrm{kg}$.

For tradable input costs, it can be seen that tradable input costs of private prices are lower than social prices. This is due to the provision of subsidies for fuel and LPG gas from the government. Consequently, fish entrepreneurs/ fishermen paid for these tradable inputs lower than they should be. Meanwhile, domestic input costs of private prices are much higher than social prices. This revealed that the price paid by entrepreneurs/fishermen at private prices is higher than it should be paid in social prices. The income of the tuna business in the research area was profitable, both the actual and the social price level that was indicated by its positive value.

Based on the PAM table, it was obtained the values of several indicators related to the impact of government policies in the commodity. The indicators were NPCO, NPCI, PC, EPC, SRP, IT, and OT.

The Nominal Protection Coefficient Output (NPCO) value was 0.49 (smaller than one) indicating that the government policy did not implement protective policies on the output price of tuna. Therefore, the private price or the actual price of tuna in the research area was lower than the social price. The non-protective policy can be seen in the price of tuna output which continuously fluctuates in the harvest season. Though the price of tuna was determined by the market mechanism, if the lowest price and the highest price set by the government, the output price of tuna would be relatively stable. If the rupiah exchange rate is unstable, the possibility of rupiah value is strong, the export volume will increase. While, if the rupiah exchange rate is weak, the export volume will decreases. So that it causes losses for tuna entrepreneurs because it can reduce the income.

The Nominal Protection Coefficient Input (NPCI) value in the tuna commodity business in the research area was $0.58 \mathrm{NPCI}$ which was less than one, indicating that the domestic price of tradable input used in the tuna commodity business was lower than the world price due to fuel and LPG gas subsidies. In addition, the NPCI of 58\% indicated that the government was reducing world prices by $42 \%$. This was reflected in the provision of subsidized fuel provided by the government to fishermen. The NPCI value which is less than one also causes a transfer of income from tradable input producers to tuna fishermen in the research area.

The Profitability Coefficient (PC) value was a comparison between income at private 
prices and at social prices. The value of PC was 0.33. It showed that tuna fishermen in the research area have a private advantage of 0.33 times greater than what they should receive. By the existence of a policy in the form of fuel subsidies in the research area, the value of PC will increase that will result in the increase in private profits obtained by tuna entrepreneurs even though the provision of fuel subsidies is limited.

The Effective Protection Coefficient (EPC) indicates the impact resulting from combined transfers caused by the existence of policies (tradable input transfers and tradable output transfers) in tuna fish business. The EPC value was 0.47 indicating that government policy was categorized as protective. The policy in the form of limiting fuel subsidies in the research area has a negative impact on the benefits obtained. The reduced quota for fuel subsidies means that fishermen have to pay higher on production inputs (diesel fuel) so that their private profits will be lower than their social benefits.

Subsidy Ratio to Producer (SRP) was used to measure the whole impact of transfers which shows the changes in tuna business income related to transfers. The SRP was negative about -0.44 , indicating that there was a policy distortion. The policy of limiting fuel subsidies caused the decreasing of the received about $44 \%$.

Input Transfer (IT) remains the difference between tradable input costs at private prices and tradable input costs at social prices. Based on the results, the IT value was IDR. 5.363 per $\mathrm{kg}$ or 93.641.390 divergence that has negative value causes there was at transfer of resources into the tuna fish business which is fuel subsidies. By the fuel subsidy, it means that fishermen will only pay IDR 74.160.000 even though fishermen were supposed to pay IDR 150.154.083, - and the remaining of IDR 75.994.083, - was paid by the government (in the form of subsidies). If the policy of reducing the quota for fuel subsidies was applied continuously, fishermen will spend more on costs that will reduce profits from revenue.

Output Transfer (OT) is the dissimilarity between revenue at private prices and revenue at social prices. Based on the results, the value of OT was -675.343 .808 , -. This shows that the private benefits obtained are smaller than the social benefits. In addition, a negative OT value indicates that there is a transfer from producers to consumers so that consumers buy tuna at a lower price than it should be. This is in accordance with the literature by (Sukmaya, 2013) that the input transfer indicator shows that the government is implementing a subsidized policy on fertilizer input used by soybean farmers. Meanwhile, based on the output transfer indicator, it shows that the government policy towards the price of soybean output is more profitable for consumers, because consumers receive a lower price than the actual price.

Based on the value of EPC and NPC for the input and output obtained, it showed that there are input subsidies, taxes, trade restrictions, while fishermen did not receive output subsidies. Thus, people receive more benefits than fishermen as well as fishermen get a negative incentive effect from government policies on tradable commodity markets. The tuna commodity in Malang, seen from the DRC and PCR values, which showed a value of less than one, still has a comparative and competitive advantage in competitiveness. This is in line to what was stated by (Luhur, 2012) if measured from the DRC value. The DRC value was recorded to be less than 1 , which is 0.98 , which means that to produce IDR 1 only requires domestic resources of IDR 0.98. This means that businesses have more comparative advantages and are more competitive than seaweed cultivation in East Lombok Regency. Besides that, according to (Ningsih, 2016) a business is said to have a competitive advantage which is marked by a PCR value $<1$ and has a high comparative advantage marked by a DRCR value $<1$. In addition, the existence of government policies on tradable input production in the form of subsidies is very beneficial for farmer's business.

\section{Conclusion}

From the results of the research that has been done, it can be concluded that the government policy regarding input subsidies, taxes, trade restrictions or exchange rates is not appropriate and the public is more benefited by the output policy compared to fishermen at TPI Pondokdadap, Sumbermanjing Wetan, Malang Regency. Fishermen also get negative incentive effects from government policies on tradable commodity markets. Even so, the tuna commodity is still able to compete in the international market. This is indicated by the Domestic Resource Cost Ratio (DRCR) value of 0.21 and the Private Cost Ratio (PCR) value of 
0.46 which means that the DRCR and PCR values are <1, which means that this tuna commodity has a comparative and competitive advantage.

\section{References}

Elbadawi, et al (2012) 'Assessing the competitiveness of sheep production in selected states in Sudan.', Journal of Agricultural Science, 5(1), pp. 75-83.

Ghofar, A. (2008) Selected Indonesian Fisheries Subsidies: Quantitative and Qualitative Assessment of Policy Coherence and Effectiveness, The Nature Conservation Coral Triangle. Bali.

Gray, C. (1992) Pengantar Evaluasi Proyek. Jakarta: PT Gramedia Pustaka.

Hermawan, M. (2006) Keberlanjutan perikanan tangkap skala $K=$ kecil : Studi perikanan pantai di Serang dan Tegal. Institut Pertanian Bogor.

Kementerian Kelautan dan Perikanan (2018) Data Statistik Komoditas Ekspor Utama Perikanan.

Luhur, E. (2012) 'Analisa Daya Saing Rumput Laut Di Indonesia (Studi Kasus: Kabupaten Konawe Selatan, Sulawesi Tenggara)', J. Sosek KP, 7(1).

Mira (2014) 'Dampak Keniakan Harga BBM Terhadap Kinerja Sektor Kelutan dan Perikanan', J. Sosek KP, 9(2).

Monke, E. a and Pearson, S. R. (1989) The Policy Analysis Matrix for Agricultural Development, Outreach Program. doi: 10.1080/03768359008439507.

Muchlisin, Z. et al. (2012) 'Analisis subsidi perikanan non BBM di Kabupaten Aceh Besar, Provinsi Aceh. Fisheries subsidy analysis on non-fuel in Aceh Besar District, Aceh Province', Depik, 3(1), pp. 175-182.

Ningsih, V. (2016) 'Competitiveness Analysis of Tilapia Grower Business of Small Farmers in Musi Rawas Regency', AGRISEP, 15(2), pp. 279-291.

Pearson, E. a. (2005) Aplikasi Policy Analysis Matrix Pada Pertanian Indonesia. Jakarta: Yayasan Obor Indonesia.
Poernomo, A. and Heruwati, E. S. (2011) 'Industrialisasi Perikanan: Suatu Tantangan Untuk Perubahan', Squalen.

Putra, A. (2016) 'Agreement on Agriculture dalam World trade Organization', Jurnal Hukum dan Pembangunan, (1), pp. 90105.

Rilus, A. K. (2012) 'Konflik-Konflik Sumberdaya Alam di Kalangan Nelayan di Indonesia', SODALITY: Jurnal Sosiologi Pedesaan. doi: 10.22500/sodality.v1i1.5936.

Sukmaya, S. (2013) Analisis Daya Saing Dan Dampak Kebijakan Pemerintah Terhadap Komoditas Kedelai Vs Pengusahaan Kedelai Di Kabupaten Lamongan, Jawa Timur. Institut Pertanian Bogor. 